\title{
PENGARUH PERSEPSI PELAKSANAAN SCQI, KECERDASAN EMOSIONAL DAN KEINOVATIFAN TERHADAP ETIKA KERJA PEGAWAI
}

\author{
Aisyah A.R. \\ Ilmu Pendidikan FKIP Unsri \\ ar.aisyah@ymail.com
}

\begin{abstract}
Abstrak
Penelitian ini bertujuan untuk mengetahui pengaruh persepsi terhadap pelaksanaan sitem Continous Quality Improwen kecerdasan emosional dan keinovatifan terhadap etika kerja pegawai di kota Palembang, dengan sampel penelitian 100 pegawai yang dilakukan secara random sampling dan data dianalisis dengan teknik analisis Structural Quation Modding(SEM). Hasil analisis: 1) tidak terdapat pengaruh antara persepsi terhadap pelaksanaan sistem Continuous Quality Improwemen dan etika kerja pegawai, 2) terdapat pengaruh positif antara kecerdasan emosional dan etika kerja pegawai, 3) terdapat pengaruh positif antara persepsi terhadap pelaksanaan sistem Continuars Quality Improvement dan keinovatifan 4) terdapat pengaruh positif antara kecerdasan emosional dan keinovatifan, 5) terdapat pengaruh positif antara keinovatifan dan etika keja pegawai. D ari hasil penelitian dapat disimpulkan bahwa etika kerja pegawai dapat ditingkatkan oleh kecerdasan emosional dan persepsi terhadap pelaksanaan sistem Continuaus QualityImprovement dan keinovatifan.
\end{abstract}

Kata kunci: etika kerja, continous quality improvement system(CQI), kecerdasan emosional, keinovatifan 
Jumal Penditian danEvaluas Pendidikan

\title{
THE INFLUENCE OF PERCEPTION SCQI TOWARDS EMOTIONAL QUATION AND INOVATION TOWARDS WORK ETHIC OF EMPLOYEES AT THE GOVERMENT OFFICE
}

\author{
Aisyah A.R. \\ Ilmu Pendidikan FKIP Unsri \\ araisyah@ymail.com
}

\begin{abstract}
This study is aimed at finding out the effects of perception of the implementation of the Continuous Quality Improvement system (CQI), emotional quotient, and innovation on employees' work ethic. The study was conducted in government offices in Palembang involving 100 randomly selected employees. The data were analyzed using Structural Equation Modeling (SEM). The research findings show that: 1) there is no effect of perception of the implementation of the Continuous Q uality Improvement system on employees' work ethic, 2) there is a positive effect of employees' emotional quotient on their work ethic, 3) there is positive effect of perception of the implementation of the Continuous Quality Improvement system on innovation, 4) there is a positive effect of emotional quotient on innovation, and 5) there is a positive effect of innovation on work ethic. Based on the research findings, it can be concluded that employees' work ethic can be enhanced by improving and developing perception of the implementation of the Continuous Quality Improvement system, emotion quotient, and innovation.

Keywords: work thic continuaus qualityimproement system emotional quatient, innovation
\end{abstract}

2 - Jumal PenditiandanEvaluasi Pendidikan Edisi D ies Natalis ke-48 UNY 


\section{Pendahuluan}

Etika kerja mempunyai peranan penting dalam peningkatan kualitas dan moral pegawai. Kesadaran akan pentingnya etika kerja akan mampu mengantarkan pegawai kepada kemampuan untuk bersikap kritis dan rasional guna membentuk pendapat sendiri sesuai dengan apa yang dipilih dan dapat dipertanggungjawabkan. O leh karena itu upaya peningkatan dan pengembangan kualitas sumber daya manusia dengan daya saing tinggi, profesional dan etika yang tinggi perlu untuk terus menerus dilakukan secara terencana. Hersey \& Blanchard (1994:276) mengemukakan, perubahan-perubahan yang terjadi merupakan suatu kenyataan, sehingga pimpinan dan pegawai merupakan sumber daya manusia yang harus mampu menyusun strategi, merencanakan, mengarahkan dan mengendalikan perubahan baik perubahan pengetahuan, perubahan sikap, perubahan perilaku individual dan perubahan prestasi kelompok dan organisasi.

Dengan adanya kemampuan beradaptasi, kecerdasan emosional dan simpati, adanya persepsi dan keterlibatan yang baik terhadap sistem manajemen yang berlaku, adanya keinovatifan, memiliki perilaku yang baik dan memiliki pengetahuan, pendidikan dan pelatihan yang tinggi akan berimplikasi pada semakin meningkatnya cara kerja, disiplin dan sekaligus dapat memperlihatkan etika kerja yang tinggi. Gibson, Ivancevich, dan D onnelly (1985:9) mengatakan faktor pengaruh yang paling penting atas efektivitas setiap organisasi adalah perilaku pegawai itu sendiri. Namun tidak hanya itu yang cukup penting adalah dalam mempertahankan dan memelihara etika kerja para pegawai, semua pegawai perlu dipertimbangkan bagaimana berperilaku yang baik terutama yang berkaitan dengan nilai-nilai tentang makna yang benar dan salah yang berlaku secara objektif baik individu maupun lembaga. Berarti untuk meningkatkan etika kerja pegawai dituntut senantiasa terbuka, jujur, transparan dan mampu menjaga akuntabilitas dalam proses kerja, baik ke dalam maupun di luar instansi.

Etika kerja pegawai banyak mendapatkan kritikan dari masyarakat, karena upaya kerja pegawai sebagai sumber daya manusia yang handal belum dapat dikatakan berhasil, banyak persoalan moral pegawai di dalam 
kehidupan ini ditudingkan kepada pegawai mulai dari pegawai kecil sampai pada pejabat-pejabat fungsional. Persoalan-persoalan yang dianggap cukup serius diantaranya masalah korupsi, masalah disiplin kerja, sistem penempatan atau prosedur penempatan pegawai tidak sesuai dengan latar belakang pendidikan/pelatihan yang diikuti, datang kerja terlambat dan pulangnya cepat, saling menyalahkan dan lain-lain.

Etika kerja pegawai yang diharapkan tidak akan terwujud dalam sekejap melainkan harus diupayakan melalui proses, dan proses inipun dipengaruhi oleh banyak faktor, baik dari dalam diri individu maupun faktor lingkungan dimana individu berada. Satyanugraha (2003:60) mengemukakan bahwa tindakan yang benar secara moral itu sendiri tidak dapat dipaksakan, keyakinan akan kebenaran suatu norma moral itu sendiri datang dari diri sendiri secara otonom dan mematuhi aturan norma yang diyakini kebenarannya, juga atas keinginan diri sendiri, moralitas hanya dapat diyakini bila diri sendiri memang menginginkan itu untuk dilakukan dan juga dikatakannya standar moral berbeda dari bermacam-macam standar nonmoral, manusia memiliki prinsip-prinsip moral tertentu yang diterimanya sacara eksplisit dan implisit, bagaimana orang-orang memperoleh prinsip-prinsip moral yang dimilikinya, yaitu dari orang tua, dari lingkungan kehidupan sehari-hari, dari budaya lingkungan masyarakat kita dan pengalaman pribadi. Konsekuensi dari hal tersebut yakni dalam organisasi atau lembaga diperlukan suatu strategi yang baik untuk dapat mengelola manusia sebagai sumber daya yang memiliki etika kerja yang tinggi. Berikut dikemukakan Salam (1997:169), bahwa tingkat paling pertama manusia adalah etika yang menyangkut dengan sikap pola hidupnya yang bersumber dari nilai-nilai yang dianut seseorang di dalam hidupnya, dan nilai ini akan melahirkan moral tertentu yang dapat mempengaruhi persepsi, sikap dan tingkah laku setiap orang. Tilaar (1999:40) mengemukakan, manusia yang unggul adalah manusia yang dapat mengembangkan potensi yang ada padanya seoptimal mungkin, sehingga dengan potensi itu ia dapat bersaing dengan manusia lainnya dan dapat menghasilkan sesuatu yang berkualitas. Oleh sebab itu kinerja lembaga dapat diwujudkan pada tingkat yang lebih tinggi apabila di dukung oleh SD M yang memiliki etika kerja tinggi untuk meningkatkan prestasi kerja.

4 - Jumal PenditiandanEvaluasi Pendidikan Edisi D ies Natalis ke-48 UNY 
Strategi atau sistem pelaksanaan manajemen organisasi dalam hal ini lembaga/ institusi khususnya sistem manajemen Continuaus Quality Improement (CQI) yang digunakan organisasi dalam peningkatan kualitas organisasi/ instansi secara terus menerus perlu diperhatikan. Pembinaan dan pengembangan instansi yang baik melalui visi dan misi lembaga akan dapat memberikan hasil dan dampak positif bagi lembaga. Oleh karena itu pembinaan dan pengembangan sistim CQ I harus dilakukan secara kontinu, sungguh-sungguh, terarah dan terencana, sehingga akhirnya akan cenderung membuat disiplin, dapat merencanakan pekerjaan dengan baik, etika kerja yang meningkat. Persepsi pegawai yang baik terhadap strategi yang kompetitif dengan sistem CQI, merupakan suatu kekuatan untuk mendukung terselenggaranya instansi dan membangun organisasi secara nasional yang berkemajuan, seperti penerapan sistem Kaizen di Jepang. Kaizen merupakan konsep organisasi yang menerapkan CQI dengan perbaikan yang berkesinambungan dan sangat berhasil, karena di dalam penerapan prinsip Kaizen faktor manusia merupakan dimensi yang terpenting dalam perbaikan kualitas dan produktivitas organisasi (Tjiptono dan D iana, 1995:262).

Keinovatifan merupakan hal yang esensial bagi setiap karyawan, seorang yang memiliki keinovatifan melalui ide, cita dan pikiran dalam bekerja cenderung adanya loyalitas terhadap individu lain, memahami perasaan dan kepedulian sesama rekan sekerja dan atasan yang tentunya akan berdampak positif terhadap keberhasilan organisasi, seperti dikatakan Sheila Resenberg (2000:187-188). Kelompok yang memiliki semangat yang tinggi dalam bekerja lebih baik hasilnya dari pada kelompok yang hanya memiliki sedikit semangat tim, dan bila individu itu ditempatkan di posisi sentral dalam kelompok maka bekerjanya lebih baik daripada bekerja sendirian. Jelas bahwa keterlibatan individu dalam kegiatan kelompok dengan keinovatifan yang tinggi merupakan semangat tersendiri dalam bekerja untuk mencapai tujuan.

Mengingat pentingnya hal ini perlu kiranya melakukan penelitian secara mendalam mengenai dampak penerapan sistem Continaus Quality Improwement, yang dilihat dari persepsi pegawai terhadap pelaksanaannya, keinovatifan, kecerdasan emosional baik langsung atau tidak langsung 
terhadap etika kerja pegawai. Hasil penelitian ini akan memperoleh rekomendasi dan masukan yang bersifat konstruktif untuk meningkatkan etika kerja pegawai dalam menunjang etika organisasi, instansi dan lembaga. Terkait dengan permasalahan tersebut, penelitian ini bertujuan untuk mempelajari pengaruh persepsi terhadap pelaksanaan sitem Continas Quality Improvemen kecerdasan emosional dan keinovatifan terhadap etika kerja pegawai di kota Palembang.

\section{Metode Penelitian}

Penelitian ini menggunakan pendekatan kuantitatif. Populasi penelitian adalah pegawai eselon III di kota Palembang yang berjumlah 100 orang. Jumlah sampel yang didapatkan memenuhi persyaratan untuk menggunakan tehnik analisis Structural Equation Modding (SEM). Hipotesis dalam penelitian ini adalah (1) Terdapat pengaruh persepsi pelaksanaan sistem Contimuaus Quality Improvement (CQI) terhadap etika kerja , (2) Terdapat pengaruh kecerdasan emosional terhadap etika kerja, (3) Terdapat pengaruh persepsi terhadap sistem Continuous Quality Improvement (CQI) terhadap keinovatifan, (4) Terdapat pengaruh kecerdasan emosional terhadap keinovatifan, (5) Terdapat pengaruh keinovatifan terhadap etika kerja. Model metamatis persamaan struktural atau diagram jalur untuk persamaan struktural dan notasi yang digunakan dalam model matematika penelitian yang sekaligus menunjukkan bagaimana hipotesis yang akan diuji dalam penelitian ini, tergambar dalam gambar berikut:

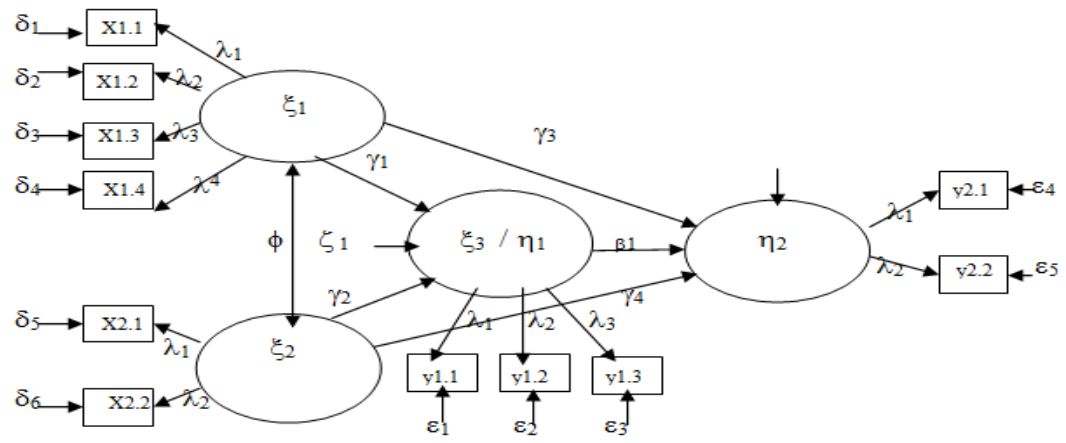

Gambar 1. Model matematis persamaan struktural dan notasi penelitian

6 - Jumal PenditiandanEvaluasi Pendidikan Edisi D ies Natalis ke-48 UNY 
Data dikumpulkan dengan menggunakan instrumen berbentuk kuesioner yang dikembangkan oleh peneliti. Kuesioner diujicobakan kepada sebanyak 40 responden dan selanjutnya dilakukan pembuktian validitas dan estimasi reliabilitas instrumen.

Teknik analisis yang digunakan yakni Structural Equation Modding (SEM), yang merupakan teknik yang menggunakan confimatory factor atau analisis faktor, analisis regresi berganda dan analisis jalur (path analysis). Langkah-langkah analisis data meliputi 7 langkah pemodelan SEM, yaitu 1) pengembangan model secara teoretis, 2) menyusun diagram jalur, 3) mengubah diagram jalur menjadi persamaan struktural, 4) memilih matrik input, 5) menilai identifikasi model, 6) mengevaluasi estimasi model, 7) iterpretasi model.

\section{Hasil Penelitian dan Pembahasan}

\section{a. Uji Normalitas}

Pengujian normalitas diperoleh nilai z-scre skenness dan kurtorsis dengan memperhatikan daerah penerimaan, dinyatakan normal (z-scoredan nilai $\left.\chi^{2} \leq 2,58\right)$.

Tabel 1. Hasil uji normalitas variabel variabel laten Etika Kerja

\begin{tabular}{|c|c|c|c|c|c|c|}
\hline Variabel & \multicolumn{2}{|c|}{ Skennesc } & \multicolumn{2}{c|}{ Kurtaris } & \multicolumn{2}{c|}{ Skenness\& kurtarsis } \\
\hline & z-score & p-value & z-score & p-value & $\chi^{2}$ & p-value \\
\hline $\mathrm{Y}_{2.1}$ & 0,129 & 0,897 & $-0,265$ & 0,971 & 0,087 & 0,957 \\
\hline $\mathrm{Y}_{2.2}$ & 0,139 & 0,890 & $-0,269$ & 0,788 & 0,092 & 0,955 \\
\hline
\end{tabular}

Hasil uji nomalitas variabel laten Keinovatifan

\begin{tabular}{|c|c|c|c|c|c|c|}
\hline \multirow{2}{*}{ Variabel } & \multicolumn{2}{|c|}{ Skennesc } & \multicolumn{2}{c|}{ Kurtaris } & \multicolumn{2}{c|}{ Skenness \& kurtaris } \\
\hline & Z-score & p-value & Z-score & p-value & $\chi^{2}$ & p-value \\
\hline$Y_{1.1}$ & 0,182 & 0,885 & $-0,398$ & 0,691 & 0,191 & 0,909 \\
\hline$Y_{1.2}$ & $-0,059$ & 0,953 & $-0,031$ & 0,976 & 0,004 & 0,998 \\
\hline$Y_{1.3}$ & $-0,088$ & 0,930 & $-0,104$ & 0,917 & 0,019 & 0,991 \\
\hline
\end{tabular}


Jumal Penditian danEvaluas Penddikan

Hasil uji normalitas variabel laten Persepsi Terhadap Pelaksanaan CQ I

\begin{tabular}{|c|c|c|c|c|c|c|}
\hline Variabel & \multicolumn{2}{|c|}{ Skennesc } & \multicolumn{2}{c|}{ Kuntaris } & \multicolumn{2}{c|}{ Skenness \& kuntasis } \\
\hline & z-score & p-value & z-score & p-value & $\chi^{2}$ & p-value \\
\hline $\mathrm{X}_{1.1}$ & $-0,170$ & 0,865 & $-0,254$ & 0,800 & 0,093 & 0,954 \\
\hline $\mathrm{X}_{1.2}$ & 0,038 & 0,970 & $-0,216$ & 0,829 & 0,084 & 0,976 \\
\hline $\mathrm{X}_{1.3}$ & 0,000 & 1.000 & $-0,077$ & 0,938 & 0,006 & 0,997 \\
\hline $\mathrm{X}_{1.4}$ & 0,019 & 0,985 & $-0,126$ & 0,900 & 0,016 & 0,992 \\
\hline
\end{tabular}

Hasil uji normalitas variabel laten Kecerdasan Emosional

\begin{tabular}{|c|c|c|c|c|c|c|}
\hline Variabel & \multicolumn{2}{|c|}{ Skewnsc } & \multicolumn{2}{c|}{ Kurtaric } & \multicolumn{2}{c|}{ Skenness\& kurtaris } \\
\hline & z-score & p-value & z-score & p-value & $\chi^{2}$ & p-value \\
\hline $\mathrm{X}_{2.1}$ & 0,106 & 0,915 & $-0,162$ & 0,872 & 0,037 & 0,981 \\
\hline $\mathrm{X}_{2.2}$ & $-0,106$ & 0,916 & $-0,177$ & 0,907 & 0,025 & 0,988 \\
\hline
\end{tabular}

Uji normalitas dari setiap indikator dari semua variabel laten dinyatakan normal, karena $\chi^{2}$ dan $p$-value $\leq t_{\text {tabel }} 2,58(0.005)$ dan $t_{\text {tabel }} 1,96$ $(0,001)$.

\section{b. Hasil uji linienitas}

Tabel 2. Rangkuman hasil uji linieritas variabel laten

\begin{tabular}{|l|l|l|l|}
\hline \multirow{2}{*}{ Variabel } & \multicolumn{3}{|c|}{ Linearitas } \\
\cline { 2 - 4 } & $\mathrm{F}_{\mathrm{h}}$ & \multicolumn{2}{|c|}{$\mathrm{F}_{\mathrm{t}}$} \\
\cline { 2 - 4 } & & 0,05 & 0,01 \\
\hline $\mathrm{Y}_{2} \mathrm{X}_{1}$ & 1,35 & 1,67 & 2,08 \\
\hline $\mathrm{Y}_{2} \mathrm{X}_{2}$ & 1,73 & 1,82 & 1,52 \\
\hline $\mathrm{Y} \mathrm{X}_{3}\left(\mathrm{Y}_{1}\right)$ & 1,64 & 1,67 & 2,08 \\
\hline $\mathrm{X}_{3}\left(\mathrm{Y}_{1}\right) \mathrm{X}_{1}$ & 1,45 & 1,82 & 1,52 \\
\hline $\mathrm{X}_{3}\left(\mathrm{Y}_{1}\right) \mathrm{X}_{2}$ & 1,70 & 1,71 & 2,13 \\
\hline
\end{tabular}

Linearitas $\mathrm{F}_{\mathrm{h}}<\mathrm{F}_{\mathrm{t}}$

Uji linieritas variabel laten dapat dilihat dari garis persamaan regresi, hasil perhitungan terbukti $\mathrm{F}_{\text {hitung }}<\mathrm{F}_{\text {tabel }}$.

\section{c. Hasil uji 0 utlier}

Uji outlier distandardisasi dalam bentuk z-scremempunyai rata-rata nol dengan standar deviasi sebesar satu.

8 - Jumal PenditiandanEvaluasi Pendidikan Edisi D ies Natalis ke-48 UNY 
Tabel 3. Hasil uji outlier variabel laten

\begin{tabular}{|l|c|c|c|c|c|}
\hline \multicolumn{1}{|c|}{ Z-Score Varabel } & $\mathrm{N}$ & Minimum & Maksimum & Mean & St.deviasi \\
\hline z scre etika kerja & 100 & $-3,05$ & 2,23 &, 00 & 1,00 \\
\hline z-scre kec.emosional & 100 & $-2,73$ & 1,84 &, 00 & 1,00 \\
\hline z-scre persep. CQ I & 100 & $-2,73$ & 1,84 &, 00 & 1,00 \\
\hline z-scat keinovatifan & 100 & $-3,53$ & 1,94 &, 00 & 1,00 \\
\hline
\end{tabular}

Dari tabel diatas terlihat tidak ada nilai z-score yang lebih dari 3.0, nilai rata-rata sama dengan nol, standar deviasi sebesar satu, berarti tidak ada outlier dari data yang dianalisis.

\section{d. Hasil uji Multicollinieritas dan Singularitas variabel laten}

Tabel 4. Hasil uji multikolinearitas dan singularitas variabel laten

\begin{tabular}{|l|c|c|}
\hline Variabel Laten & Kovarians & Extrendlysmall $\geq 0,00$ \\
\hline $\mathrm{YX}_{1}$ & 0,59 & 0,00 \\
\hline $\mathrm{YX}_{2}$ & 0,66 & 0,00 \\
\hline $\mathrm{YX}_{3}\left(\mathrm{Y}_{1}\right)$ & 0,71 & 0,00 \\
\hline $\mathrm{X}_{1} \mathrm{X}_{3}\left(\mathrm{Y}_{1}\right)$ & 0,68 & 0,00 \\
\hline $\mathrm{X}_{2} \mathrm{X}_{3}\left(\mathrm{Y}_{1}\right)$ & 0,65 & 0,00 \\
\hline
\end{tabular}

Hasil uji multicollinieritas dan singularitas variabel memperlihatkan deteminant matric covarians lebih besar dari 0,00 , berarti data tidak memiliki masalah atau kovarians $\geq 0,00$ memberi indikasi tidak adanya masalah milticdlinieitas dan singularitas

\section{e. Hasil Uji Analisis Muatan Faktor}

Hasil analisis dari setiap muatan faktor dari variabel penelitian dapat dilihat dalam tabel berikut:

Tabel 5. Muatan faktor dalam variabel

Muatan faktor pada indikator variabel laten E tika Kerja

\begin{tabular}{|l|c|c|c|c|c|}
\hline \multirow{2}{*}{ Indikator } & \multirow{2}{*}{$\begin{array}{l}\text { Muatan faktor/ } \\
\text { Std-Loading }\end{array}$} & \multirow{2}{*}{$\begin{array}{c}\text { Standar } \\
\text { Kesalahan }\end{array}$} & \multicolumn{2}{|c|}{ CFA / Nilai t } & \multirow{2}{*}{ Keterangan } \\
\cline { 4 - 5 } & & & t-hitung & t-tabel & \\
\hline Kepribadian & 0,47 & 0,049 & 9,63 & 1,96 & Valid -/ reliabel \\
\hline Sosial & 0,51 & 0,051 & 9,96 & 1,96 & Valid -/ reliabel \\
\hline
\end{tabular}


Jumal Penditian danEvaluas Penddikan

Muatan faktor pada indikator variabel laten Keinovatifan

\begin{tabular}{|c|c|c|c|c|c|}
\hline \multirow[t]{2}{*}{ Indikator } & \multirow{2}{*}{$\begin{array}{l}\text { Muatan faktor/ } \\
\text { Std-Loading }\end{array}$} & \multirow{2}{*}{$\begin{array}{l}\text { Standar } \\
\text { Kesalahan }\end{array}$} & \multicolumn{2}{|c|}{ CFA / Nilai t } & \multirow[b]{2}{*}{ Keterangan } \\
\hline & & & t-hitung & t-tabel & \\
\hline Pengadopsian & 0,40 & & 0,24 & 1,96 & V alid -/ reliabel \\
\hline Penciptaan & 0,33 & 0,043 & 7,51 & 1,96 & V alid -/ reliabel \\
\hline Tindakan & 0,28 & 042 & 6,62 & 6,62 & V alid -/ reliabel \\
\hline
\end{tabular}

Muatan faktor pada indikator variabel laten Contimuaus QualityImprovent

\begin{tabular}{|c|c|c|c|c|c|}
\hline \multirow[b]{2}{*}{ Indikator } & \multirow{2}{*}{$\begin{array}{l}\text { Muatan faktor/ } \\
\text { Std-Loading }\end{array}$} & \multirow{2}{*}{$\begin{array}{c}\text { Standar } \\
\text { kesalahan }\end{array}$} & \multicolumn{2}{|c|}{ CFA / Nilai t } & \multirow[b]{2}{*}{ Keterangan } \\
\hline & & & t-hitung & $\mathrm{t}$-tabel & \\
\hline Pendapat & 0,25 & 0,051 & 4,97 & 1,96 & Valid -/ reliabel \\
\hline P.Kategorian & 0,45 & 0,046 & 9,77 & 1,96 & Valid -/ reliabel \\
\hline Penafsiran & 0,49 & 0,042 & 11,75 & 1,96 & Valid -/ reliabel \\
\hline Tanggapan & 0,44 & 0,048 & 9,01 & 1,96 & Valid -/ reliabel \\
\hline
\end{tabular}

Muatan faktor pada variabel laten Kecerdasan Emosional

\begin{tabular}{|l|c|c|l|l|l|}
\hline & Muatan faktor/ & \multirow{2}{*}{$\begin{array}{c}\text { Standar } \\
\text { Indikator }\end{array}$} & Std-Loading & CFA / Nilai t & \multirow{2}{*}{ kesalahan } \\
\cline { 4 - 5 } & t-hitung & t-tabel & Keterangan \\
\hline $\begin{array}{l}\text { Kemampuan } \\
\text { Personal }\end{array}$ & 0,49 & 0,049 & 10,09 & 1,96 & Valid -/ reliabel \\
\hline $\begin{array}{l}\text { Kemapuan } \\
\text { Sosial }\end{array}$ & 0,43 & 0,038 & 11,40 & 1,96 & Valid -/ reliabel \\
\hline
\end{tabular}

Muatan faktor dari setiap variabel laten diperlihatkan dari Confimatory Factor Analysis (CFA) atau nilai t. Dalam LISREL diperlihatkan dari Maximm Likdihood Apabila $t_{\text {hitung }} \geq$ dari $t_{\text {tabel }}$ menunjukkan muatan vaktor valid dan reliabel. Hasil yang didapatkan dari faktor menunjukan $t_{\text {hitung }} \geq t_{\text {tabel }}$ berarti semua faktor valid dan reliabel untuk semua variabel.

\section{f. Pengujian model dan hipotesis (tahap pertama)}

Setelah analisis model struktural dilakukan, maka hasil perhitungan yang diperoleh maka dapat untuk menguji hipotesis. Semua hipotesis akan didukung bila koefisien $\Gamma_{1}$ bernilai positif dan signifikan pada level $p=<0.005$. Tingkat signifikan tersebut diuji dengan membandingkan nilai Critical Ratio(CR) statistik dengan $t_{\text {tabel }}$ pada degreof freelom(df).

10 - Jumal Penditian danEvaluasi Pendidkan Edisi D ies Natalis ke-48 UNY 


\section{Hasil uji hipotesis penelitian:}

\section{Penganuh persepsi terhadap sistem Continuous Quality I mprovement terhadap etika kerja}

Formula untuk menguji: $\eta_{2}=\Gamma_{1} \xi_{1}+\zeta_{2}$

Hipotesis yang diuji : $\quad \mathrm{H}_{0}: \lambda_{\text {ye }} 1=0 \quad \mathrm{H}_{\mathrm{a}}: \lambda_{\text {ye }} 1>0$

Dani hasil perhitungan diperoleh nilai koefisien jalur $\left(\lambda_{\text {ye }} 1\right) \quad 0,06$ dengan $t_{\text {hitung }}=0,76\left(t_{\text {tabel }} 1,96=0,005\right)$ dan $\left(t_{\text {tabel }} 2,58=0,001\right)$ atau $t_{h} 0,76$ $\leq t_{t} 1,96(0.005)$ dan 2,58 (0,001), maka koefisien jalur tidak signifikan, sehingga jalur dihapuskan untuk pengujian berikut. D apat dikatakan tidak terdapat pengaruh langsung antara pelaksanaan sistem Continuous Quality Improwemt terhadap etika kerja.

\section{Pengaruh kecerdasan emosional terhadap etika kerja pegawai}

Formula untuk menguji : $\quad \eta_{2}=\Gamma_{2} \xi_{2}+\zeta_{2}$

Hipotesis yang diuji : $\quad \mathrm{H}_{0}: \lambda_{\text {ye }} 2=0 \quad \mathrm{H}_{\mathrm{a}}: \lambda_{\mathrm{ye}} 2>0$

Dari hasil perhitungan diperoleh nilai koefisien jalur $\left(\lambda_{\text {ye }} 1\right) \quad 0,31$ dengan $t_{\text {hitung }}=5,25\left(t_{\text {tabel }} 1,96=0,005\right)$ dan $\left(t_{\text {tabel }} 2,58=0,001\right)$ atau $t_{h} 5,25$ $\geq t_{t} 1,96(0.005)$ dan 2,58 (0,001), maka koefisien jalur positif dan signifikan, sehingga jalur dapat diteruskan untuk pengujian berikut. Dapat dikatakan terdapat pengaruh langsung antara kecerdasan emosional terhadap etika kerja.

\section{Pengaruh persepsi terhadap sistem Continuous Quality I mprovement terhadap keinovatifan}

Formula untuk menguji: $\quad \eta_{1}=\Gamma_{1} \xi_{1}+\zeta_{1}$

Hipotesis yang diuji : $\quad \mathrm{H}_{0}: \lambda_{\mathrm{ye}} 1=0 \quad \mathrm{H}_{\mathrm{a}}: \lambda_{\text {ye }} 1>0$

Dari hasil perhitungan diperoleh nilai koefisien jalur $\left(\lambda_{\text {ye }} 3\right) \quad 0,69$ dengan $t_{\text {hitung }}=8,42 \quad\left(t_{\text {tabel }} 1,96=0,005\right)$ dan $\left(t_{\text {tabel }} 2,58=0,001\right)$ atau $t_{h}$ $8,42 \geq t_{t} 1,96(0.005)$ dan 2,58 (0,001), maka koefisien jalur positif dan signifikan, sehingga jalur dapat diteruskan untuk pengujian berikut. Dapat dikatakan terdapat pengaruh langsung antara persepsi terhadap sistem Continuars QualityImproemet terhadap keinovatifan 
Jumal Penditian danEvaluas Pendidikan

\section{Penganuh kecendasan emosional terhadap keinovatifan}

Formula untuk menguji: $\quad \eta_{1}=\Gamma_{2} \xi_{2}+\zeta_{1}$

Hipotesis yang diuji : $\quad \mathrm{H}_{0}: \lambda_{\text {ye }} 2=0 \quad \mathrm{H}_{\mathrm{a}}: \lambda_{\text {ye }} 2>0$

Dari hasil perhitungan diperoleh nilai koefisien jalur $\left(\lambda_{\text {ye }} 4\right) \quad 0,34$ dengan $t_{\text {hitung }}=4,35\left(t_{\text {tabel }} 1,96=0,005\right)$ dan $\left(t_{\text {tabel }} 2,58=0,001\right)$ atau $t_{h} 4,35$ $\geq t_{t}$ 1,96 (0.005) dan 2,58 (0,001), maka koefisien jalur positif dan signifikan, sehingga jalur dapat diteruskan untuk pengujian berikut. Dapat dikatakan terdapat pengaruh langsung antara kecerdasan emosional terhadap keinovatifan.

\section{Penganuh keinovatifan terhadap etika kerja}

Formula untuk menguji: $\quad \eta_{2}=\beta_{1} \xi_{2}+\zeta_{2}$

Hipotesis yang diuji : $\quad \mathrm{H}_{0}: \lambda_{\text {ye }} \beta_{1}=0 \quad \mathrm{H}_{\mathrm{a}}: \lambda_{\text {ye }} \beta_{1}>0$

Dari hasil perhitungan diperoleh nilai koefisien jalur $\left(\lambda_{\text {ye }} 4\right) \quad 0,48$ dengan $t_{\text {hitung }}=5,33\left(t_{\text {tabel }} 1,96=0,005\right)$ dan $\left(t_{\text {tabel }} 2,58=0,001\right)$ atau $t_{h} 5,33$ $\geq t_{t} 1,96(0.005)$ dan 2,58 (0,001), maka koefisien jalur positif dan signifikan, sehingga jalur dapat diteruskan untuk pengujian berikut. Dapat dikatakan terdapat pengaruh positif antara keinovatifan terhadap etika kerja pegawai.

Hasil uji pengaruh variabel laten dan koefisien jalur pada uji pertama

Tabel 6. Hasil Perhitungan dan Penyajian Koefisien Jalur

\begin{tabular}{|c|c|c|c|c|l|}
\hline J a l u r & Koefisien & $\mathrm{t}$ - hitung & \multicolumn{2}{|c|}{$\mathrm{t}$ - tabel } & \multirow{2}{*}{ Keterangan } \\
\cline { 4 - 5 } & Jalur & & 0,005 & 0,001 & \\
\hline$\eta_{2} \xi_{1}+\zeta_{2}$ & 0,06 & 0,76 & 1,96 & 2,58 & $\begin{array}{l}\text { Koefisien tidak signifikan } \\
\text { jalur dihapuskan }\end{array}$ \\
\hline$\eta_{2} \xi_{2}+\zeta_{2}$ & 0,31 & 5,25 & 1,96 & 2,58 & Sangat signifikan \\
\hline$\eta_{1} \xi_{1}+\zeta_{1}$ & 0,69 & 8,42 & 1,96 & 2,58 & Sangat signifikan \\
\hline$\eta_{1} \xi_{2}+\zeta_{1}$ & 0,34 & 4,35 & 1,96 & 2,58 & Sangat signifikan \\
\hline$\eta_{2} \eta_{1}+\zeta_{2}$ & 0,48 & 5,33 & 1,96 & 2,58 & Sangat signifikan \\
\hline
\end{tabular}

12 - Jumal PenditiandanEvaluasi Pendidkan Edisi D ies Natalis ke-48 UNY 
Jumal Penditian dan Evaluasi Pendidkan



Chi-Square $=92.13, d f=38, P-v a l u e=0.00000$, RMSEA $=0.098$

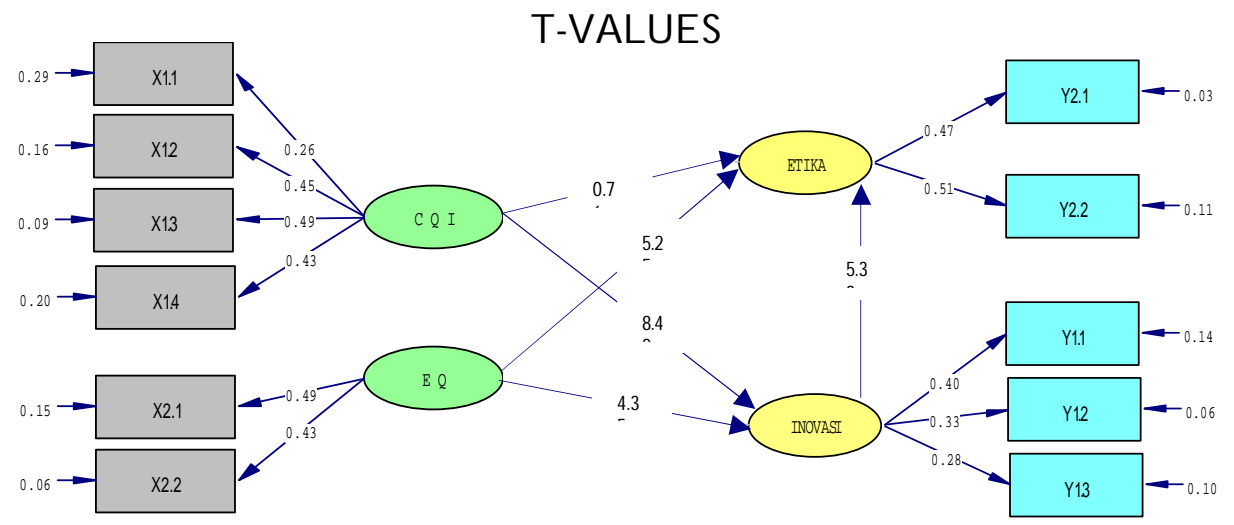

92.66, $d f=39, \quad P-v a l u e=0.00000$, RMSEA $=0.097$

Gambar 2. Hasil analisis Lisrel pada uji pertama

PenganuhPesppi PdaksanaanSCQI - 13 Aistyah AR 


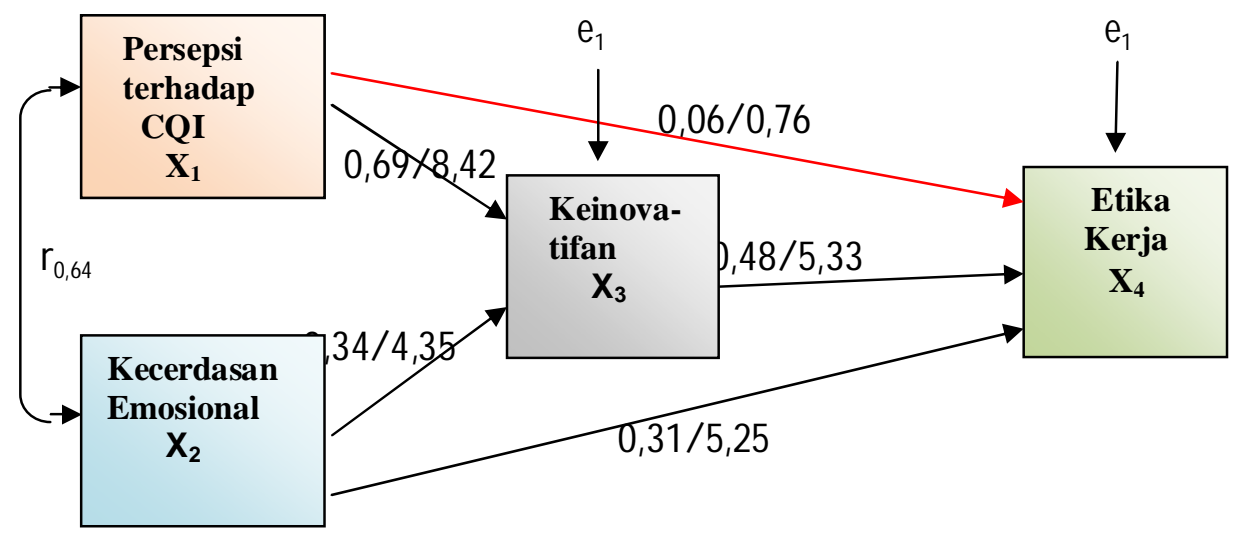

Gambar 3. Hasil Uji Model Hubungan Struktural Antar Variabel Tahap Pertama

\section{g. Hasil uji koefisien jalur model struktural yang dimodifikasi (tahap kedua)}

Jalur yang nilai koefisien tidak signifikasi (berarti) dihapuskan dari model yang diajukan. Setelah itu dilakukan kembali perhitungan nilai koefisien jalur dengan model yang baru dan diuji keberartian dari setiap variabel. Perhitungan nilai koefisien untuk setiap jalur dilakukan kembali dengan menggunakan uji keberartian setiap variabel laten. Adapun rincian hasil perhitungan koefisien jalur model yang imodifikasi dijelaskan dalam tabel berikut:

Tabel 7. Hasil Perhitungan dan Penyajian Model Struktural yang D imodifikasi

\begin{tabular}{|c|c|c|c|c|c|}
\hline J a l u r & Koefisien & $\mathrm{t}$ - hitung & \multicolumn{2}{|c|}{$\mathrm{t}$ - tabel } & \multirow{2}{*}{ Keterangan } \\
\cline { 4 - 5 } & Jalur & & 0,005 & 0,001 & \\
\hline$\eta_{2} \xi_{1}+\zeta_{1}$ & 0,66 & 14,97 & 1,96 & 2,58 & Pengaruh sangat signifikan \\
\hline$\eta_{1} \xi_{2}+\zeta_{2}$ & 0,60 & 14,51 & 1,96 & 2,58 & Pengaruh sangat signifikan \\
\hline$\eta_{1} \xi_{2}+\zeta_{2}$ & 0,51 & 10,75 & 1,96 & 2,58 & Pengaruh sangat signifikan \\
\hline$\eta_{2} \eta_{1}+\zeta_{2}$ & 0,59 & 11,50 & 1,96 & 2,58 & Pengaruh sangat signifikan \\
\hline
\end{tabular}

14 - Jumal Penditian danEvaluasi Pendidkan Edisi D ies Natalis ke-48 UNY 
Uji tahap ke dua (terahir) pengaruh antara variabel CQI, kecerdasan emosional, keinovatifan dan etika kerja pegawai



Chi-Square=92.66, df=39, P-value=0.00000, RMSEA=0.097

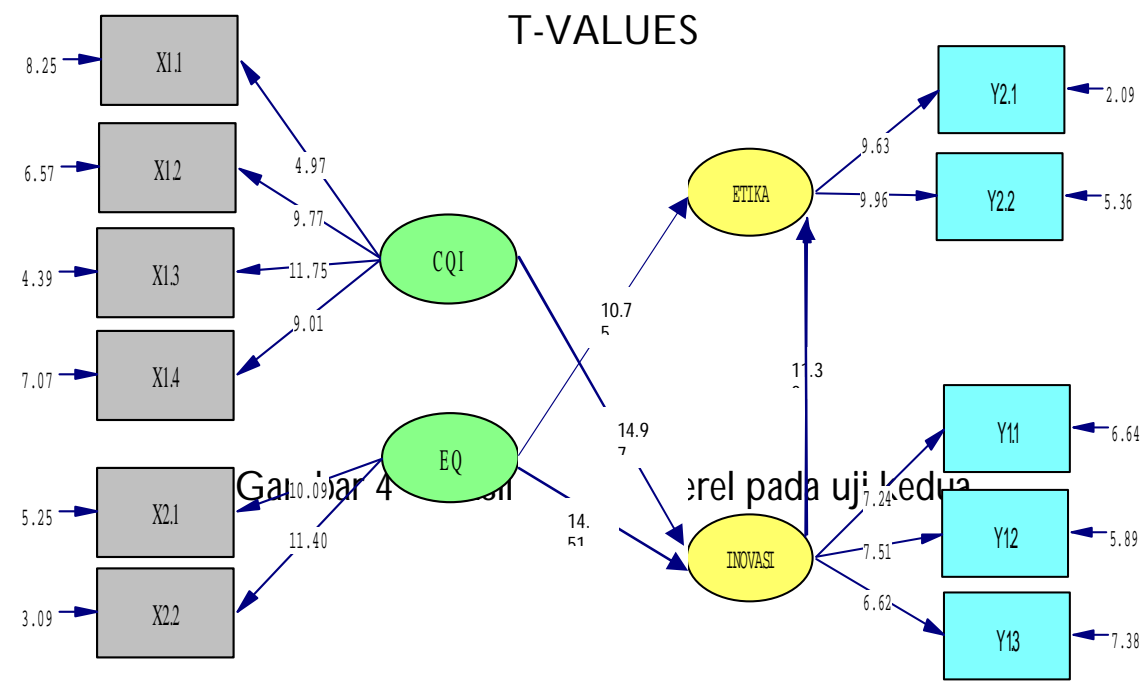

Chi-Square=92.66, df=39, P-value $=0.00000$, RMSEA $=0.097$

G ambar 4. Hasil analisis liserel pada uji kedua

PenganuhPesppi PdaksanaanSCQI -15 Aistyah AR 




Gambar 5. Hasil Uji Model Hubungan Struktural antar Variable Tahap kedua

\section{h. Goodness-of-fit index untuk kesesuaian model hubungan struktural antar variabel}

Model struktural penelitian yang dibangun berdasarkan hipotesis yang diuji melalui LISERL. Untuk mengukur kesesuain model penelitian ini menggunakan Goodnessof-fit index dengan tiga cara melihat 1) absdut fit modd, 2) incemental modd dan 3) persimmius modd. Hasilnya didapatkan dalam tabel berikut:

Tabel 8. Hasil uji kesesuain model struktural

\begin{tabular}{|c|c|c|c|c|}
\hline No & Ukuran & Ketentuan & $\begin{array}{l}\text { Model awal } \\
\text { penelitian }\end{array}$ & $\begin{array}{l}\text { Model akhir } \\
\text { penelitian }\end{array}$ \\
\hline \multicolumn{5}{|c|}{ AcsduteFit/ Modd Fit } \\
\hline 1 & DF & D iharapkan kecil & 38 & 39 \\
\hline 2 & $\chi^{2}$ & D iharapkan kecil & 92,13 & 92,66 \\
\hline 3 & GFI & $\geq 0,90$ & 0,90 & 0,95 \\
\hline 4 & RMR & $<0,05$ & 0,017 & 0,018 \\
\hline 5 & RMSEA & $<0,05$ & 0,0016 & 0.0020 \\
\hline \multicolumn{5}{|c|}{ Imenental Fit } \\
\hline & AGFI & $\geq 0,90$ & 0,82 & 0,93 \\
\hline 7 & NFI & $\geq 0,90$ & 0,87 & 0,890 \\
\hline \multicolumn{5}{|c|}{ ParsimmiusFit } \\
\hline 8 & PGFI & Semakin TinggiSemakin Baik & 0,52 & 0,54 \\
\hline 9 & PNFI & Semakin TinggiSemakin Baik & 0,60 & 0,61 \\
\hline 10 & P (Sigificante) & $\geq 0,05$ & 0.00 & 0,05 \\
\hline
\end{tabular}

16 - Jumal PenditiandanEvaluasi Pendidkan Edisi D ies Natalis ke-48 UNY 
Jumal Penditian dan Evaluasi Pendidkan

Keterangan:

$\mathrm{DF} \quad=$ Degess of freedm

GFI $=$ Goodness of Fit Index

NFI $=$ NomedFit Indx

$\mathrm{RMR}=$ Rot MeanSquareReidual

PNFI = Parsimmy NomedFitIndex

PGFI = ParsimonyGoodness of Fit Index

AGFI = Adusted Goodness of FitIndx

RMSEA =Rot MeanSquareEmor of Appriximation

Tabel 9. Rekapitulasi Hasil Pengujian Hipotesis

\begin{tabular}{|c|c|c|c|c|}
\hline No & Hipotesis & Uji Signifikan & Keputusan & Keterangan \\
\hline 1 & $\begin{array}{l}\text { Persepsi terhadap } \\
\text { pelaksanaan sistem CQ I } \\
\text { berpengaruh langsung } \\
\text { terhadap etika kerja }\end{array}$ & $\begin{array}{l}\eta_{2}=\Gamma_{1} \xi_{1}+\zeta_{2} \\
\mathrm{H}_{0}: \lambda_{\text {ye }} 1=0 \\
\mathrm{H}_{\mathrm{a}}: \lambda_{\text {ye }} 1>0\end{array}$ & $\begin{array}{l}\mathrm{H}_{0} \\
\text { diterima }\end{array}$ & $\begin{array}{l}\text { Memiliki pengaruh } \\
\text { tak langsung dan } \\
\text { tidak dimasukkan } \\
\text { dalam mo difikasi } \\
\text { model }\end{array}$ \\
\hline 2 & $\begin{array}{l}\text { Kecerdasan emosional } \\
\text { berpengaruh langsung } \\
\text { terhadap etika kerja }\end{array}$ & $\begin{array}{l}\eta_{2}=\Gamma_{2} \xi_{2}+\zeta_{2} \\
\mathrm{H}_{0}: \lambda_{\text {ye }} 2=0 \\
\mathrm{H}_{\mathrm{a}}: \lambda_{\text {ye }} 2>0\end{array}$ & $\mathrm{H}_{0}$ ditolak & $\begin{array}{l}\text { Memiliki pengaruh } \\
\text { langsung }\end{array}$ \\
\hline 3 & $\begin{array}{l}\text { Persepsi terhadap } \\
\text { pelaksanaan sistem CQ I } \\
\text { berpengaruh langsung } \\
\text { terhadap keinovatifan }\end{array}$ & $\begin{array}{l}\eta_{1}=\Gamma_{1} \xi_{1}+\zeta_{1} \\
\mathrm{H}_{0}: \lambda_{\text {ye }} 1=0 \\
\mathrm{H}_{\mathrm{a}}: \lambda_{\text {ye }} 1>0\end{array}$ & $\mathrm{H}_{0}$ ditolak & $\begin{array}{l}\text { Memiliki pengaruh } \\
\text { langsung }\end{array}$ \\
\hline 4 & $\begin{array}{l}\text { Kecerdasan emosional } \\
\text { berpengaruh langsung } \\
\text { terhadap keinovatifan }\end{array}$ & $\begin{array}{l}\eta_{1}=\Gamma_{2} \xi_{2}+\zeta_{1} \\
\mathrm{H}_{0}: \lambda_{\text {ye }} 2=0 \\
\mathrm{H}_{\mathrm{a}}: \lambda_{\text {ye }} 2>0\end{array}$ & $\mathrm{H}_{0}$ ditolak & $\begin{array}{l}\text { Memiliki pengaruh } \\
\text { langsung }\end{array}$ \\
\hline 5 & $\begin{array}{l}\text { Keinovatifan berpengaruh } \\
\text { langsung tehadap etika kerja }\end{array}$ & $\begin{array}{l}\eta_{2}=\beta_{1} \xi_{2}+\zeta_{2} \\
H_{0}: \lambda_{\text {ye }} \beta_{1}=0 \\
H_{a}: \lambda_{\text {ye }} \beta_{1}>0\end{array}$ & $\mathrm{H}_{0}$ ditolak & $\begin{array}{l}\text { Memiliki pengaruh } \\
\text { langsung }\end{array}$ \\
\hline
\end{tabular}

\section{Pembahasan}

Muatan faktor dan Confimatory Factor Analysis (CFA) pada setiap variabel dapat dilihat dari factor loadingyang diperoleh dari setiap variabel. Pada variabel etika kerja dari dua muatan faktor cukup tinggi yaitu keperibadian 0,47 (47 \%) dan sosial 0,51 (51 \%). Muatan faktor variabel keinovatifan pada pengadopsian 0,40 (40\%), penciptaan 0,33 (33\%), dan tindakan 0,28 (28 \%). Muatan faktor variabel persepsi terhadap 
pelaksanaan sistem CQ I pada pendapat 0,25 (25\%), pengkategorian 0,45 (45\%), penafsiran 0,49 (49\%), dan tanggapan 0,44 (44\%). Muatan faktor variabel laten kecerdasan emosional pada kemampuan personal 0,49 (49 $\%)$, dan kemampuan sosial 0,43 (43 \%). Hal ini menunjukkan bahwa faktor-faktor dari setiap variabel endogen atau variabel eksogen cukup tinggi untuk membentuk indikator, sehingga terlihat model fit dengan data dan tahap analisis dapat dilanjutkan.

Hasil analisis pemodelan struktural tahap pertama (koefisien jalur) yaitu menguji pengaruh antara dua variabel eksogen (persepsi terhadap CQI dan kecerdasan emosional) dengan variabel endogen lainnya (keinovatifan). Variabel endogen (keinovatifan) dengan variabel endogen lainnya (etika kerja). Hasilnya menunjukkan bahwa persepsi terhadap pelaksanaan sistem CQI (eksogen) dengan keinovatifan (endogen) 0,69, $\mathrm{t}=$ 8,42, kecerdasan emosional (eksogen) dengan keinovativan (endogen) 0,34 dengan $t=4,35$. Keinovatifan (eksogen) dengan etika kerja (endogen) $0,48, t=5,33$. Persepsi terhadap pelaksanaan sistem CQI (eksogen) dengan etika kerja (endogen) 0,06 dengan $t=0,76$, kecerdasan emosional (eksogen) dengan etika kerja (endogen) $0,31, t=5,25$. Hasil di atas memperlihatkan persepsi terhadap pelaksanaan CQI tidak berpengaruh langsung terhadap etika kerja, karena koefisien pengaruh lebih kecil dari $t=1,96(0,05)$, sedangkan variabel eksogen lainnya berpengaruh langsung terhadap etika kerja.

Hasil analisis jalur pemodelan struktural yang dimodifikasi atau analisis struktural tahap kedua, yaitu menguji pengaruh antara dua variabel eksogen (persepsi CQI dan kecerdasan emosional) terhadap variabel endogen (etika kerja) dan satu variabel endogen (keinovatifan) dan variabel endogen lainnya (etika kerja). Hasilnya menunjukkan bahwa ada peningkatan dan ada penununan jumlah pengaruh antara variabel eksogen. Hasilnya adalah, persepsi terhadap pelaksanaan sistem CQI (eksogen) dengan keinovatifan (endogen) 0,66, $\mathrm{t}=14,97$, kecerdasan emosional (eksogen) dengan keinovatifan (endogen) 0,60, $t=14,51$ kecerdasan emosional dengan keinovatifan $0,51, t=10,75$, keinovatifan (eksogen) dengan etika kerja (endogen) $0,59, t=11,30$.

18 - Jumal Penditian danEvaluasi Pendidkan Edisi D ies Natalis ke-48 UNY 
Hasil uji hipotesis pengaruh persepsi terhadap pelaksanaan sistem CQI dengan etika kerja pegawai pada pemodelan struktur terbukti kecil dan dapat dikatakan tidak berpenganuh dan tidak signifikan. D engan sub indikator faktor pandangan, pengkategorian, penafsiran dan tanggapan terhadap perbaikan proses, perbaikan sumber daya manusia dan perbaikan evaluasi itu setiap individu memberikan arti kepada stimulus. Hal tersebut mendukung apa yang dikemukan Nord (1976) bahwa persepsi individu merupakan proses pemberian arti terhadap lingkungan dan setiap individu memberikan arti yang berbeda terhadap terhadap barang yang sama dengan cara yang berbeda. Demikian juga dalam teori Risenberg (2000) efek, kognisi dan perilaku menentukan sikap dan selanjutnya sikap menentukan efek, kognisi dan perilaku, sehingga wajar apabila persepsi pegawai tidak berpengaruh terhadap etika kerja pegawai.

Hasil uji hipotesis pengaruh kecerdasan emosional terhadap etika kerja pegawai pada pemodelan truktural pertama dan modifikasi pemodelan terbukti berpenganuh dan signifikan. Dengan indikator kemampuan personal dalam kesadaran diri, pengaturan diri, dan evaluasi diri, secara integratif berpengaruh terhadap etika kerja. Soloso (1995) mengungkapkan emosi penting dan berpengaruh sebagai energi pengaktif untuk nilai-nilai etika (kepercayaan, integritas, empati, keuletan) dalam mempertahankan hubungan yang saling percaya dan etika. D emikan juga Agustian (2000) berpendapat kecerdasan emosional yang meliputi unsur suasana hati, kesadaran diri, motivasi, etos kerja, keyakinan, integritas, komitmen, konsistensi, kejujuran, daya tahan dan keterbukaan, berhubungan erat dengan etika kerja seseorang.

Hasil uji hipotesis penganuh persepsi terhadap pelaksanaan CQ I dengan keinovatifan pada pemodelan struktur pertama dan modifikasi pemodelan terbukti berpenganuh dan signifikan. Dengan indikator pandangan, pengkategorian, penafsiran dan tanggapan terhadap perbaikan proses, perbaikan SDM dan perbaikan evaluasi, secara integratif berpengaruh terhadap keinovatifan dalam wujud pengadopsian, penciptaan dan tindakan terhadap gagasan, layanan, alat dan pengetahuan tentang pekerjaan. D ikatakan Liberg bahwa keinovatifan bukan hanya dipengaruhi sebagai proses berpikir kreatif melainkan juga sebagai kapabilitas 
melahirkan, mengembangkan dan merubah gagasan/ inovatif, proses,produk layanan, model atau perilaku tertentu.

Hasi uji hipotesis pengaruh kecerdasan emosional terhadap keinovatifan pada pemodelan struktur awal dan modifikasi pemodelan terbukti berpengaruh dan signifikan. Dengan indikator kemampuan personal (intrepersonal) dengan kesadaran diri, pengaturan diri dan evaluasi diri, secara integratif berpengaruh terhadap keinovatifan dalam wujud pengadopsian, penciptaan dan tindakan terhadap gagasan, layanan, alat dan pengetahuan tentang pekerjaan. Seperti dikemukakan Goleman (1995) bahwa kecerdasan emosional bermanfaat untuk memahami cara kerja dalam kehidupan individu. Ada lima dimensi kecerdasan emosional dan dua puluh lima kecakapan emosi, diantaranya dikatakan bahwa kemampuan diri dapat menciptakan sinergi kelompok, melahirkan ede baru dan imajinatif dalam memperjuangkan tujuan bersama.

Hasil uji hipotesis pengaruh keinovatifan terhadap etika kerja pegawai pada pemodelan struktur awal dan modifikasi pemodelan terbukti signifikan. D engan indikator pengadopsian, penciptaan, dan tindakan terhadap gagasan, layanan, alat dan pengetahuan tentang pekerjaan, secara integartif berpengaruh terhadap etika kerja. Cambiac (2004) mengemukakan perilaku kratif dan inovatif dapat menggerakkan dan memungkinkan berkembangnya hubungan yang harmonis dan etika baik dalam bekerja.

Dari hasil penelitian dapat diimplikasikan bahwa untuk meningkatkan etika kerja pegawai adalah meningkatkan pengaruh dari semua faktor yang ada dalam tiga variabel eksogen yaitu persepsi terhadap pelaksanaan sistem Continous Quality Improvemm kecerdasan emosional dan keinovatifan kerja pegawai. Akan tetapi dari ketiga variabel atau faktor yang berpengaruh langsung hanya dua faktor yaitu kecerdasan emosional dan keinovatifan terhadap etika kerja, sedangkan satu variabelnya sangat kecil dan tidak berpengaruh langsung terhadap etika kerja pegawai yaitu persepsi terhadap pelaksanaan sistem CQ I, namun variabel atau faktor ini sangat tinggi berpengaruh pada variabel keinovatifan sebagai variabel endogen. Keinovativan sebagai variabel endogen juga cukup tinggi dipengaruhi oleh kecerdasan emosional. Sedangkan variabel keinovatifan 
sebagai variabel endogen cukup tinggi mempengaruhi etika kerja pegawai, hal ini cenderung disebabkan sudah terpengaruhnya variabel keinovatifan oleh variabel atau faktor persepsi terhadap pelaksanaan sistem CQI dan kecerdasan emosional.

Sehingga ketiga variabel atau faktor eksogen tersebut merupakan faktor yang potensial dapat mempengaruhi dan meningkatkan etika kerja pegawai, sedangkan persepsi terhadap pelaksanaan sistem CQ I meskipun tidak berpengaruh langsung terhadap etika kerja, namun faktor ini memiliki pengaruh yang tinggi melalui keinovatifan, berarti semua variabel eksogen merupakan faktor yang masih perlu dipertahankan dalam meningkatkan etika kerja pegawai.

\section{Simpulan}

Dani hasil penelitian dapat disimpulkan bahwa etika kerja pegawai dapat ditingkatkan oleh kecerdasan emosional dan persepsi terhadap pelaksanaan sistem ContinuausQualityImprovemen dan keinovatifan.

\section{Saran}

Berdasarkan hasil penelitian ini dapat diajukan beberapa saran sebagai berikut:

1. Perlu adanya penambahan pengetahuan, terhadap pegawai sehingga tidak sering salah persepsi. Pegawai sekaligus pimpinan harus memiliki nilai (value) karena nilai sangat akrap dengan sikap dan perilaku, nilai dan perilaku tidak hanya mempengaruhi persepsi,tetapi juga sebagai alat untuk mencapai tujuan.

2. Hasil penelitian menunjukkan adanya pengaruh kecerdasan emosional terhadap etika kerja dan keinovatifan, berarti peningkatan kecerdasan emosional merupakan kebutuhan yang perlu dijaga melalui berbagai kegiatan. Untuk itu perlu: a). Upaya menanamkan kebiasaan dalam memecahkan setiap kasus yang dapat meningkatkan kematangan emosi dan meningkatkan daya nalar mengenai kasus tertentu, b) 
Pelatihan kepemimpinan bagi pegawai pejabat eselon agar dapat meningkatkan keterampilan dalam mengenal fungsi organisasi, kesadaran akan kelebihan dan kekurangan diri sendiri.

3. Hasil penelitian menunjukkan bahwa keinovatifan merupakan variabel yang paling tinggi pengaruhnya terhadap etika kerja pegawai, Oleh karena itu perlu adanya peningkatan keinovatifan sehingga pegawai eselon III mampu lebih inovatif terhadap tugas-tugas kerja yang akanberdampak pada etika kerjanya.

\section{Daftar Pustaka}

Agustian, Ary Gunanjar, (2000). ESQ Bedasarkan 6 rukun Islam Jakarta: Arga.

Badan Kepegawaian Daerah Pemerintah Kota Palembang. (2004). Kepegamaian dalam angka. Laporan Badan Kepegawaian Daerah Pemerintah Kota Palembang. Tidak dipublikasikan.

Cambiac, Rice, (2004). Organization Credivity, Diunduh dan http// / wuwssida.com/ shtm, tanggal 3 A pril 2004.

Gibson, James L, Jhon M. Ivancevich. James Donnelly. Robert Konopaske. (2006). Organization: Behaviar, Structural, Process NewYork: The McG raw-Hill Companies, Inc.

G oleman, D aniel. (1995). Emotional Inteligence Why it Can Matter More Than IQ. New-York : A Bantam Book

Hersey and Kennet Blanchard. (1973). Managent of Organizational Bahavior. UtilizingHuman Raseres Engelword Cliffs. New Jersey: Printice Hall International E ditions.

Liberg, K urt R, (2002). http/ / uwwaurwoddcompusemvecam

Nord.W.R, (1976). Concepts snd Controversy in Organizational Behavia, Santamonica, Calif, G oodyer

22 - Jumal PenditiandanEvaluasi Pendidkan Edisi D ies Natalis ke-48 UNY 
Jumal Penditian dan Evaluasi Pendidkan

Rasenberg, Sheila, (2000). Memimin Manusia: Si Manajemen Sumber Daya

Manusia, dalam A D ale Tempe, Jakarta: PT G ramedia

Soloso, Robert L, (1995), CognitivePsychdogy, Needham: Allin and Bacon.

Tillaar, H.A.R., (1997). Pengenbangan SDM dalamEra Gldbalisas, Visi, Misi dan ProgramAks Pendidkan danPdatihan Jakarta: P.T. G rasindo.

Tjiptono, Fandy dan Anatasia Diana, (1995). Tdal Quality Managment, Yogyakarta: Andi Offet. 